Binghamton University

The Open Repository @ Binghamton (The ORB)

$12-20-2017$

\title{
Integration of unaccompanied migrant youth in the United States: a call for research
}

\author{
Jodi Berger Cardoso \\ University of Houston, jcardoso@central.uh.edu \\ Kalina Brabeck \\ Rhode Island College \\ Dennis Stinchcomb \\ American University \\ Lauren Heidbrink \\ California State University, Long Beach \\ Olga Acosta Price \\ George Washington University
}

See next page for additional authors

Follow this and additional works at: https://orb.binghamton.edu/hdev_fac

Part of the Social and Behavioral Sciences Commons

\section{Recommended Citation}

Cardoso, Jodi Berger; Brabeck, Kalina; Stinchcomb, Dennis; Heidbrink, Lauren; Price, Olga Acosta; GilGarcia, Oscar F.; Crea, Thomas M.; and Zayas, Luis H., "Integration of unaccompanied migrant youth in the United States: a call for research" (2017). Human Development Faculty Scholarship. 15.

https://orb.binghamton.edu/hdev_fac/15

This Article is brought to you for free and open access by the Human Development at The Open Repository @ Binghamton (The ORB). It has been accepted for inclusion in Human Development Faculty Scholarship by an authorized administrator of The Open Repository @ Binghamton (The ORB). For more information, please contact ORB@binghamton.edu. 


\section{Authors}

Jodi Berger Cardoso, Kalina Brabeck, Dennis Stinchcomb, Lauren Heidbrink, Olga Acosta Price, Oscar F. Gil-Garcia, Thomas M. Crea, and Luis H. Zayas 


\section{Integration of unaccompanied migrant youth in the United States: a call for research}

Jodi Berger Cardoso, Kalina Brabeck, Dennis Stinchcomb, Lauren Heidbrink, Olga Acosta Price, Óscar F. Gil-García, Thomas M. Crea \& Luis H. Zayas

To cite this article: Jodi Berger Cardoso, Kalina Brabeck, Dennis Stinchcomb, Lauren Heidbrink, Olga Acosta Price, Óscar F. Gil-García, Thomas M. Crea \& Luis H. Zayas (2017): Integration of unaccompanied migrant youth in the United States: a call for research, Journal of Ethnic and Migration Studies, DOI: 10.1080/1369183X.2017.1404261

To link to this article: https://doi.org/10.1080/1369183X.2017.1404261

曲 Published online: 20 Dec 2017.

Submit your article to this journal

III Article views: 26

Q View related articles $\sqsubset$

View Crossmark data $₫$

4 Citing articles: 1 View citing articles 둔 


\title{
Integration of unaccompanied migrant youth in the United States: a call for research
}

\author{
Jodi Berger Cardoso ${ }^{\mathrm{a}}$, Kalina Brabeck ${ }^{\mathrm{b}}$, Dennis Stinchcomb ${ }^{\mathrm{c}}$, Lauren Heidbrink ${ }^{\mathrm{d}}$, \\ Olga Acosta Price ${ }^{\mathrm{e}}$, Óscar F. Gil-García ${ }^{\mathrm{f}}$, Thomas M. Crea ${ }^{\mathrm{g}}$ and Luis H. Zayas ${ }^{\mathrm{h}}$
}

${ }^{a}$ Graduate College of Social Work, University of Houston, Houston, TX, USA; 'Department of Counseling, Educational Leadership \& School Psychology, Rhode Island College, Providence, RI, USA; 'Center for Latin American \& Latino Studies, American University, Washington, DC, USA; ${ }^{d}$ Department of Human Development, California State University, Long Beach, CA, USA; ${ }^{e}$ Department of Prevention and Community Health, Milken Institute School of Public Health, The George Washington University, Washington, DC, USA; ${ }^{H}$ Human Development Department, Binghamton University, Binghamton, NY, USA; ${ }^{9}$ School of Social Work, Boston College, Newton, MA, USA; ${ }^{\mathrm{h}}$ School of Social Work, The University of Texas at Austin, Austin, TX, USA

\begin{abstract}
Between October 2013 and July 2016, over 156,000 children travelling without their guardians were apprehended at the U.S.-Mexico border and transferred to the care of the Office of Refugee Resettlement (ORR). During that same period, ORR placed over 123,000 unaccompanied migrant youth - predominantly from Central America - with a parent or other adult sponsor residing in the U.S. Following placement, local communities are tasked with integrating migrant youth, many of whom experience pre- and in-transit migration traumas, family separation, limited/interrupted schooling, and unauthorised legal status, placing them at heightened risk for psychological distress, academic disengagement, maltreatment, and human trafficking. Nonetheless, fewer than $10 \%$ of young people receive formal post-release services (PRS). This paper addresses the paucity of research on the experiences of the $90 \%$ of children and youth without access to PRS. To bridge this gap, this article: (a) describes the post-release experiences of unaccompanied youth, focusing on legal, family, health, and educational contexts; (b) identifies methodological and ethical challenges and solutions in conducting research with this population of young people and their families; and (c) proposes research to identify structural challenges to the provision of services and to inform best practices in support of unaccompanied youth. [196 words]
\end{abstract}

\section{KEYWORDS}

Unaccompanied minors; refugees; child migration; Central America; post-release services

The number of unaccompanied migrant youth ${ }^{1}$ apprehended at the U.S.-Mexico border peaked in fiscal year (FY) 2014 to 68,541, nearly double the number of children apprehended the year prior (see Figure 1). Three-fourths of these youth came from Honduras, El Salvador, and Guatemala (CBP 2015).

Despite a decrease in FY2015, FY2016 was the second highest year on record (CBP 2016). This paper summarises empirical knowledge regarding the experiences of unaccompanied migrant youth who remain in the U.S. subsequent to their release from 


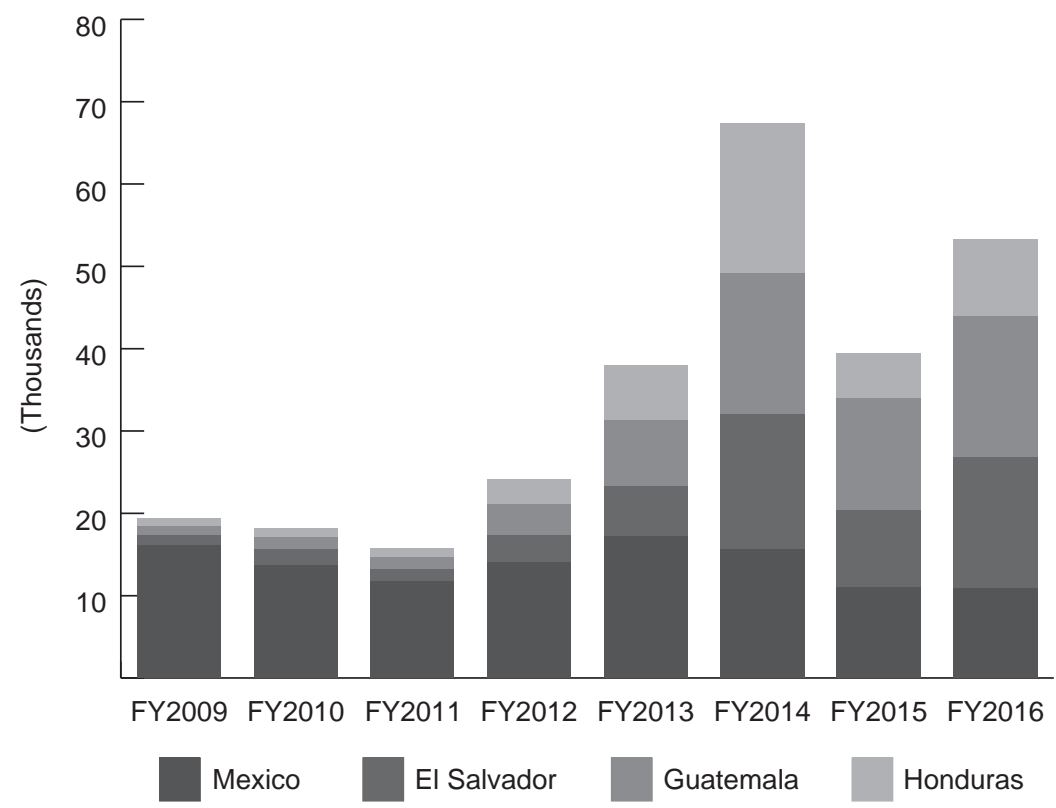

Figure 1. Unaccompanied Migrant Youth Apprehensions on the U.S.-Mexico Border. Data Source: U.S. Customs and Border Protection.

federal custody. We contextualise these experiences within pre-migration experiences that motivate migration.

While this paper emphasises the risks and challenges experienced by unaccompanied youth, we recognise that they possess equally compelling (although less researched) strengths and resiliency, both internally and in their environment. (See Figure 2 for a holistic conceptual summary of individual and ecological sources of risk and resiliency for unaccompanied migrant youth).

The push and pull factors that underlie the most recent waves of child migration to the U.S. are multifaceted (Chavez and Menjívar 2010). Parental migration increases the likelihood that children and youth will migrate (Donato and Sisk 2015). Interviews with small, non-representative samples of unaccompanied migrant youth underscore how generalised societal violence in Central America incites children to flee (UNHCR 2014). These findings are supported by the region's staggering homicide rates, with Honduras, El Salvador, and Guatemala ranked first, fourth, and fifth, respectively, for homicides rates outside of war zones in 2012 (UNODC 2014, 126). Violent crimes are largely perpetrated by increasingly sophisticated transnational gangs. Legacies of civil war and genocide, manifest in high levels of government corruption and impunity, allow gangs and other organised crime groups to assume considerable power over communities (Stinchcomb and Hershberg 2014, 21-24). The domestic sphere has also become a stage for violence, with reports of child abuse, neglect, and abandonment figuring prominently among some children's motives for migration (UNHCR 2014).

This generalised climate of violence has its roots in deep structural inequalities born of centuries of oligarchic rule, decades of civil wars (e.g. El Salvador, Guatemala), U.S. foreign and economic policy toward the region, and repeated devastation wreaked by natural 
POST-MIGRATION

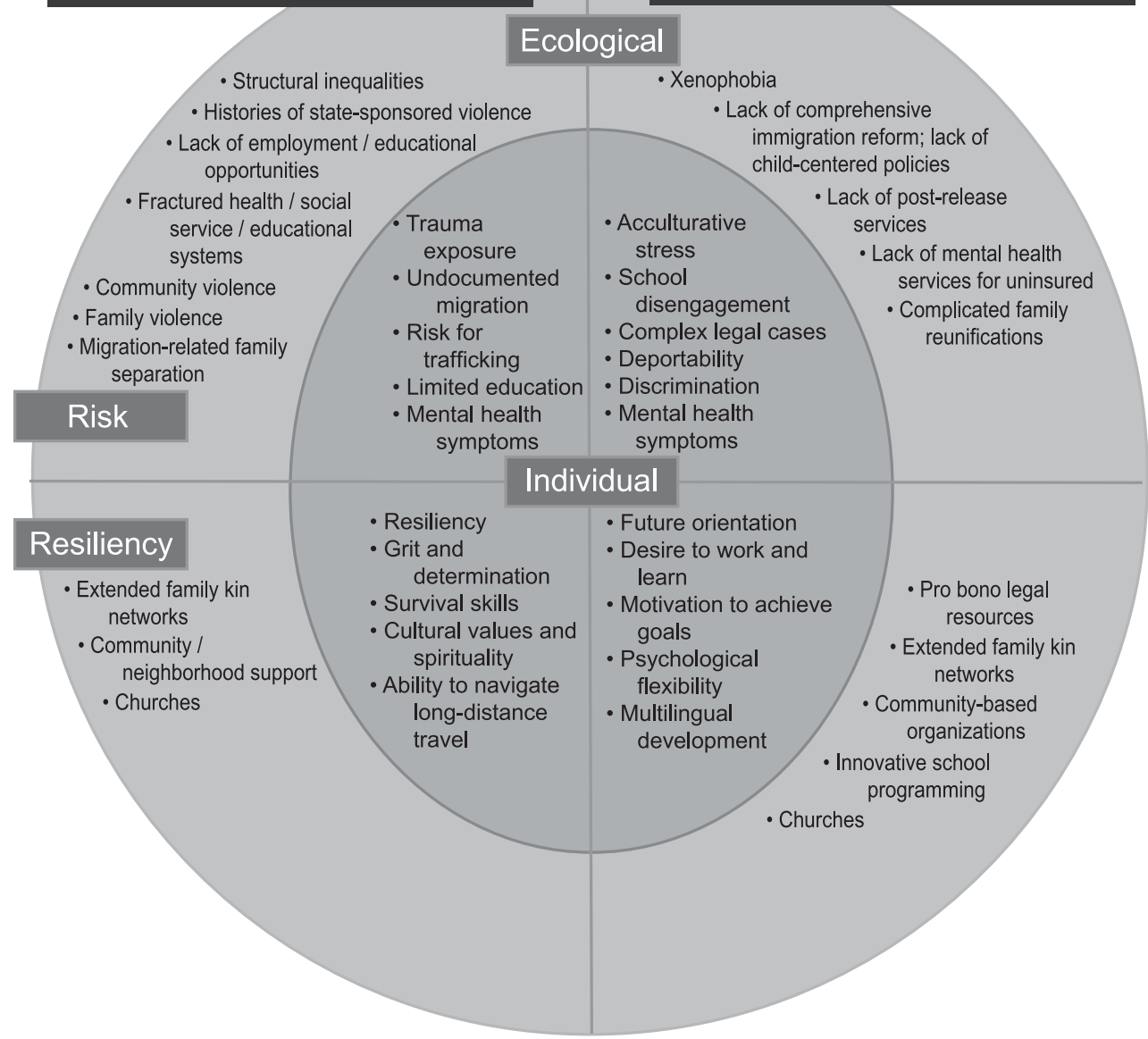

Figure 2. Pre-, Peri-, and Post-Migration Sources of Ecological and Individual Risk and Resiliency.

disasters. Scarce employment opportunities and the failure of state institutions to provide minimal resources or services have left many households without the means to support children (Stinchcomb and Hershberg 2014, 16-17). In this context, the U.S. is an attractive destination, offering children safety and an opportunity to reunite with relatives, attend school, and find employment. Enterprising human smugglers have capitalised on these pull factors and disseminated misinformation about U.S. immigration policies as part of their marketing strategy (Stinchcomb and Hershberg 2014, 12-13).

Under the William Wilberforce Trafficking Victims Protection Reauthorization Act (TVPRA) of 2008, unaccompanied youth from non-contiguous countries are processed differently than Mexican or Canadian children. Following identification by U.S. Customs and Border Protection (CBP), they are transferred to the Office of Refugee Resettlement (ORR) within 72 hours of apprehension. ${ }^{2}$ Although an estimated $58 \%$ of unaccompanied youth from Honduras, El Salvador, and Guatemala likely qualify for some form of immigration relief (UNHCR 2014), the TVPRA mandates that Central American children be transferred to the care of ORR irrespective of their eligibility for immigration 
benefits. Between October 2013 and July 2016, ORR placed over 123,000 unaccompanied migrant youth with an adult sponsor residing in the U.S.; approximately $90 \%$ of these youth were released to a parent or other family member (GAO 2016, 30). In FY2015, youth spent an average of 34 days in ORR custody and fewer than 2000 home studies were conducted to assess the safety conditions among the tens of thousands of child placements (2016). With fewer than $10 \%$ of youth receiving follow-up services post-release from ORR custody, very little is known about their resettlement and integration (GAO 2016, 34).

This paper, which is part of a special issue on unaccompanied and undocumented child migrants (see Menjívar and Perreira 2017), focuses on the experiences of unaccompanied migrant youth after they are released from ORR, with a primary emphasis on youth who do not receive post-release services (PRS) and, as a consequence, are at a heightened risk for psychological distress, academic disengagement, maltreatment, and human trafficking. Building on Menjívar and Perreira's (2017) overview of the post-migration experiences of unaccompanied migrant youth, this article will: (a) describe the post-release experiences of unaccompanied children and youth, focusing on legal, family, health, and educational contexts; (b) identify methodological and ethical challenges and opportunities in conducting research with this population; and (c) propose research to identify structural challenges to the provision of PRS and to inform best practices to support unaccompanied youth. Throughout, we highlight commonalities and differences between the experiences of unaccompanied youth and the broader population of undocumented immigrant youth. ${ }^{3}$ This paper is not intended to be a systematic review or a meta-analysis, but rather a first step in identifying challenges faced by unaccompanied youth in the U.S. who have been released from ORR. ${ }^{4}$

\section{Experiences of unaccompanied migrant youth post-ORR custody}

\section{PRS through ORR}

Once a CBP officer confirms that an apprehended minor is unaccompanied, the youth is placed in federal custody until ORR can identify the placement that is in the best interest of the child'. Until a more permanent placement is identified, unaccompanied youth are placed in one of three detention settings - non-secure shelter care, secure care, and transitional foster care - depending on a preliminary needs assessment (Kandel 2016,8). Once a viable adult sponsor is identified, home studies are conducted in accordance with the TVPRA only if the child is a victim of severe trafficking, has a disability, is a victim of abuse and neglect, or if the sponsor constitutes a risk to the child (e.g. maltreatment, exploitation, or trafficking). PRS are required for all youth whose sponsors undergo a home study. Referrals for PRS are also provided to youth who are identified as having extreme mental health or other needs for which social services are deemed appropriate (GAO 2016). PRS are typically provided by non-profit organisations, and may include assessment of the youth's safety and well-being, family case management, and referrals for health, mental health, and educational services.

Fewer than $10 \%$ of unaccompanied migrant youth receive PRS (GAO 2016, 34). The few studies documenting their experiences have relied on small convenience samples that limit generalisability. Roth and Grace (2015) studied unaccompanied youth 
receiving PRS and conclude that ORR has not defined the type and quantity of these supports, nor specified the purpose or anticipated outcomes of PRS for unaccompanied youth. Services are highly variable based on geographic location and the availability and accessibility of services. Roth and Grace (2015) argue that issuing PRS referrals depending on children's self-reports of severe maltreatment, exploitation, or trafficking poses a significant problem, as children likely underreport these issues to ORR screeners at detention facilities. Often, these experiences are revealed as youth adjust to living with families, after PRS referral decisions have been determined (Roth and Grace 2015). Research is lacking on unaccompanied migrant youth who do not receive PRS (Goździak 2015).

\section{Access to legal services}

One of the most immediate challenges for unaccompanied migrant youth in the postrelease context is access to legal representation (Stinchcomb and Hershberg 2014). While young people who remain in ORR custody are offered legal screenings through a network of ORR-funded providers, the federal government, states, and localities are not obliged to provide legal representation for unaccompanied youth post-release (Manuel and Garcia 2016, 21-22). Consequently, the burden of legal representation falls on the pro bono legal community. The impact of legal representation for these youth is well documented. A review of cases from FY2012-2014 found that 85\% of unaccompanied minors appearing in court without an attorney were ordered to leave the U.S.; with an attorney, however, a young person's odds of remaining in the country increased from $15 \%$ to $73 \%$ (TRAC 2014). Legal representation is critical given the majority of unaccompanied youth are eligible for immigration relief, including asylum, Special Immigrant Juvenile (SIJ) status, or visas for victims of human trafficking. ${ }^{5}$

Under intense pressure from immigrant advocacy groups, the Obama administration took modest steps to fill this service gap, launching pilot programmes through the Department of Health and Human Services (DHHS) and the Department of Justice (DOJ) to enable legal aid organisations to take on thousands of additional cases (White House 2014). Some localities, including New York City and Houston, have taken proactive steps to provide legal representation for unaccompanied youth by establishing publicprivate partnerships to fund case management (Council of the City of New York 2015; White House 2014). Despite these efforts, the representation rate for unaccompanied migrant youth nationwide remains low: 56\% nationwide, and even lower outside of major immigrant gateways (e.g. 29\% in Arizona). Without access to legal counsel, children are far less likely to appear in court and, as a result, the number of in absentia removal orders continues to climb, exceeding 18,000 since FY2014 (TRAC 2014).

Case outcomes also vary widely by geographical location. Asylum applications submitted by unaccompanied youth have a far higher rate of approval at the San Francisco Asylum Office (86\%) compared to Chicago (15\%) (Taxin 2016). Disparities among unaccompanied youth in access to legal services - and eventually legal status - have serious implications for young people's academic achievement (Goździak 2015) and psychosocial functioning (Roth and Grace 2015). Prior research with undocumented youth in general lends similarly documents the impact of legal status on a wide range of integration outcomes (Abrego and Gonzales 2013; Waters and Pineau 2015). 


\section{Custodial challenges: family reunification and child safety}

While research on family separation specific to unaccompanied migrant youth is limited, their experiences overlap with other youth who have experienced migration-related family separations. Previous research suggests that $85 \%$ of immigrant youth have been separated from at least one parent (Suárez-Orozco, Todorova, and Louie 2002). Parent-child separations are typically longer than anticipated and young people are often left in the care of extended kin members (Suárez-Orozco, Bang, and Kim 2010). While young people may draw upon extended social networks to negotiate parental absence, these substitute care arrangements vary widely and in some cases, place youth at risk for physical, emotional, and sexual abuse (USCCB 2012). Depending on the developmental age of the child, the consequences of parental separation may include emotional withdrawal, feelings of abandonment and resentment, depression, anxiety, and externalising behaviours. While for some youth these symptoms may abate over time, they often resurface during family reunification (Suárez-Orozco, Bang, and Kim 2010).

During the reunification phase, youth may simultaneously feel excitement to reunify with the parent(s) and ambivalence and grief about leaving their caregivers in the country of origin (Falicov 2014). After a honeymoon phase, both parents and children report that the long-term separation creates a sense of estrangement. Many youth feel disappointed that their parents and life in the U.S. fail to fulfil expectations (Artico 2003). Family conflict may result when parents feel that youth do not appreciate the financial and emotional sacrifice of migration, while youth feel unable to identify with and trust the parent. Prolonged parent-child separations are associated with higher incidence of family conflicts (Smith, Lalonde, and Johnson 2004). While for some, periods of family conflict are short-lived, for others they continue long after reunification (Roth and Grace 2015). Unaccompanied youth may be particularly vulnerable to strained family reunifications and exploitation when reunifications do not go well (Berger Cardoso 2017). These periods of heightened conflict, compounded by the lack of oversight by ORR, increase unaccompanied youth's risk for abuse, homelessness, and trafficking (Alvarez and Alegria 2016).

Difficult short-term adjustments and long-term conflict may also be experienced by unaccompanied migrant youth who are placed with non-parent sponsors (e.g. older cousins) with whom they have had limited contact prior to placement (Roth and Grace 2015). Youth who are placed with a non-parent sponsor and do not receive PRS may face additional challenges, like placement disruption, child maltreatment, homelessness, and trafficking (GAO 2016). The US Senate (2016) concluded that these circumstances are a direct consequence of ORR leaving youth unmonitored. In response, ORR established a National Call Center and 'well-being' calls for children within 30 days of release. Yet, to date ORR has not released data on the effectiveness of these initiatives. Youth for whom sponsors cannot be identified reside in federally run long-term residential care. Their high rates of exposure to stress and trauma put them at risk for acting out in placements and placement instability (Crea et al. 2017). Those released to a sponsor and who experience child maltreatment should have contact with the U.S. public child welfare system (CPS). Due to complications between federal and state jurisdictions, the numbers of unaccompanied youth who are involved with CPS is unknown. 


\section{Trauma, stress, and coping}

Unaccompanied migrant youth demonstrate remarkable resiliency as they overcome obstacles to reach the U.S., and some research demonstrates their ability to effectively cope with stressors associated with family separation and unaccompanied travel (Olwig and Gullov 2013) and to recover from traumatic experiences (German 2004). Youths' ability to 'make it' to a new country against multiple odds reflects their individual-level resources (e.g. belief in a higher power, grit, and cognitive flexibility) (Carlson, Cacciatore, and Klimek 2012). Research has documented that unaccompanied migrant youth score high on measures of hope, pathways (a sense of tangible goals), and agency (a belief in one's ability to attain these goals) (Jani, Underwood, and Ranweiler 2016). Many young people also benefit from ecological sources of resilience, such as strong extended family systems, peer groups, connection to culture, and involvement in community-based organisations (Carlson, Cacciatore, and Klimek 2012; Rae-Espinoza 2016). Migration may yield physical safety, new educational and economic opportunities, and connections with the new social environment, including family (Aldarondo and Becker 2011).

Young people's exposure to stressful and traumatic experiences pre-, during, and postmigration heightens their vulnerability to psychological distress (Aldarondo and Becker 2011; Kennedy 2013). During pre-migration, youth often experience poverty, community and/or family violence, and family separations that are linked to increased psychological distress (Kennedy 2013; Perreira and Ornelas 2013; Stinchcomb and Hershberg 2014; Suárez-Orozco, Bang, and Kim 2010). During migration, they are vulnerable to hunger, thirst, assault, accidental injuries, kidnapping, and sexual and physical violence (Aldarondo and Becker 2011; Infante et al. 2011). Reports estimate that as many as $60 \%$ of women and girls are sexually assaulted during their journey to the U.S. (AI 2010, 15). Following migration, in addition to challenges associated with family reunifications, undocumented young people may struggle with acculturative stress, social isolation, discrimination, unsafe schools and neighbourhoods, vulnerability of unauthorised status, and navigation of complex social service and legal institutions (De Genova and Peutz 2010; Perreira and Ornelas 2013; Pumariega and Rothe 2010). These stressors render unaccompanied youth at increased vulnerability for internalising symptoms (e.g. depression, anxiety), externalising symptoms (e.g. irritability, aggression), and posttraumatic stress symptoms (Carlson, Cacciatore, and Klimek 2012).

Because migration and deportation may fracture or disintegrate families, unaccompanied youth may experience the aforementioned stressors in the absence of a consistent, nurturing caregiver. From the toxic stress perspective (Shonkoff et al. 2012), this exacerbates the risk for the development of mental health symptoms. Research conducted with unaccompanied refugee youth in other countries (e.g. Netherlands, Belgium) reveals that they experience higher rates of anxiety, depression, conduct disorders, and PTSD, including late-onset PTSD (Smid et al. 2011) when compared with peers who migrated with a caregiver (Huemer et al. 2009).

International longitudinal research has documented the persistence of mental health symptoms among unaccompanied youth, often related to the challenges of family relationships, new family configurations, tensions with peers, uncertain roles, and acculturative differences (Suárez-Orozco, Bang, and Kim 2010; Vervliet et al. 2014). Some research suggests as high as $38 \%$ of youth in federal foster care meet the criteria for a psychiatric 
diagnosis and 33\% reported a history of substance use (USCCB 2012). The prevalence of trauma and substance use disorders may be higher in community samples. For example, in a convenience sample of unaccompanied migrant youth, roughly $60 \%$ of unaccompanied migrant youth met the criteria for posttraumatic stress disorder, $30 \%$ a depressive disorder, and 30\% reported suicidal ideation in the past year (Berger Cardoso 2017). These proportions are much higher than those found in nonclinical samples of youth; only about 5\% of youth meet the criteria for PTSD in their lifetime (Kessler et al. 2012).

Despite their susceptibility to psychiatric disorders based on their trauma exposure, unaccompanied youth are unlikely to receive adequate mental health assessment or treatment within ORR facilities (Kennedy 2013). After release from ORR facilities, youth who are not granted legal status typically cannot access mental health treatment because they are often ineligible for Medicaid and are excluded from federal benefits through the Affordable Care Act (Ciacca and John 2016). For those youth who receive legal status, obtaining health insurance can take two-to-three years. Prolonging treatment can have negative consequences, including greater impairment, homelessness, and violence (Wang et al. 2005). Moreover, mental health conditions can interfere with executive functioning skills necessary for academic success and can reduce academic engagement and achievement (Zychinski and Polo 2012).

\section{Educational barriers}

Research documents the disparities in K-12 schooling for students based on immigrant or undocumented status (Bean et al. 2011; Gonzales 2015). The 1982 U.S. Supreme Court decision in Plyler v. Doe dictates that states cannot deny children access to public education based on their immigration status; unaccompanied youth are no exception. However, sponsors or family members navigating school enrolment report considerable challenges when specific documentation such as health, education, or birth records are unattainable, or when local districts enact policies to prohibit undocumented students from participation in public school (AIC 2012; Mitchell 2015).

In 2014, the U.S. Department of Education issued guidance to state education agencies and local school districts clarifying the legal standards and ensuring undocumented youths' (including unaccompanied youth) civil right to a free and appropriate education (DOE 2014). Federal funds to districts with high numbers of unaccompanied migrant youth continue to fall short, placing a considerable financial burden on local school districts. There exists great variability in school districts' responses to unaccompanied youth, with some rapidly creating new programmes to meet their needs and others attempting to bar their enrolment (Pierce 2015).

Numerous factors continually shape the educational experiences and academic aspirations of immigrant students in general and likely affect unaccompanied youth in particular: the availability and quality of education in the country of origin, the linguistic and cultural diversity of the receiving community, school norms and teacher preferences, and the overarching local, social, and political context (Dabach 2011; Irizarry and Kleyn 2011; Martinez 2009; Zinth 2013). Pre-migration life for undocumented children is often characterised by significant economic deprivation and limited opportunities for formal schooling, thus obligating some youth to contribute economically to the household survival (Martinez 2009); this is likely to be especially true for unaccompanied youth. 
Some children report disruptions in schooling because of gang and community violence. In Honduras, for example, gang recruitment accompanied by violent reprisals against students refusing to join has forced prolonged school closures and provoked high dropout rates (Orellana 2013). Family separation may play a role in youth's academic struggles. Gindling and Poggio (2012) found that children who have been separated during migration from their parents fell further behind academically compared to peers who migrated with their parents. Because many youth lack basic academic skills, they may be placed in classes with younger students. Language acquisition and unwelcoming and hostile school environments also compound challenges to educational attainment. Many unaccompanied youth work to support households in countries or origin and the U.S., and consequently are absent from school (Martinez 2016). These barriers may contribute to school disengagement among unaccompanied youth.

Perceived discrimination, low levels of teacher support, insensitivity to the unique challenges of unaccompanied migration, and negative exchanges with school staff and peers are likely to contribute to differences in student engagement among unaccompanied youth (Irizarry and Kleyn 2011; Motti-Stefanidi and Masten 2013). Additionally, anxiety of disclosing one's legal status can reduce school engagement, as evidenced in studies with undocumented youth in general (Booi et al. 2016; Perez et al. 2009).

Unaccompanied migrant youths' complex experiences pose challenges to large systems like health and education that are insufficiently nimble to accommodate the unique needs of diverse students, and may overwhelm professionals who desire to support youth (Pierce 2015). Research with newcomer immigrant youth more broadly reveals some successful strategies such as welcome centres, newcomer hubs, parental volunteers, job training programmes, and district-wide meetings to oversee responses (Irizarry and Kleyn 2011).

\section{Methodological and ethical challenges and potential solutions to conducting research with unaccompanied migrant youth}

Many of the methodological and ethical obstacles involved in conducting research with unaccompanied youth, including questions of access, sampling, study design, and construct validity, mirror those faced by scholars working with other immigrant and refugee populations, and have been ably addressed in recent literature (Birman 2005; Hernández, Nguyen, Saetermoe, et al. 2013; Suárez-Orozco and Carhill 2008). This section furthers this scholarship by identifying idiosyncratic challenges encountered in the relatively nascent field of research on unaccompanied migrant youth in the U.S. Specifically, we anticipate the ways in which logistical constraints and the diverse composition of this immigrant subgroup impact methodological decision-making, shape researcher engagement with community partners, and necessitate heightened human subject protections.

\section{Access and sampling}

While relatively small in comparison to other unauthorised groups, the subset of unaccompanied youth is, at least in theory, more 'visible'. Mandatory attendance at removal hearings and enrolment in local schools provide researchers with multiple points of engagement. Collaboration with community service providers who serve as intermediaries is nonetheless crucial to building trust and rapport among potential participants and their 
sponsors. However, in the absence of access to ORR data with which to create a complete sampling frame for youth released into sponsor care, this reliance on service provider registries results in sampling biases.

Some of the limitations associated with convenience sampling can be compensated for with the employment of purposive sampling techniques that base inclusion criteria on extant demographic data available from ORR. Even then, obtaining a representative sample will be complicated by lack of data on unaccompanied migrant youth populations by geographical location and oversampling of youth who access community services. Unaccompanied migrant youth without legal representation, those who have left the sponsor household, and those who opt to forego schooling in order to enter the labour market are especially difficult to enrol. One possible solution involves utilising respondent-driven and other chain-referral sampling methods to achieve a more representative sample (Heckathorn 2002). The effectiveness of this strategy is largely dependent on the density of ties among unaccompanied youth within a given location, but such an approach may yield favourable results in areas where researchers expect to encounter high levels of organisation and social cohesion (e.g. Salvadorans and Hondurans in Houston). Some coauthors report increasingly limited success with referral sampling methods due to heightened immigration enforcement activities and the current administration's move to initiate criminal prosecutions and deportation proceedings against immigrant parents and guardians who help bring their children to the U.S. The use of meaningful incentives for participation and the attainment of Certificates of Confidentiality to protect research records are further potential solutions to obtaining representative samples.

\section{Within-group diversity and measurement}

Barriers to employing standard probability samples are further compounded by significant intra-group heterogeneity among unaccompanied youth. Depending on the proposed research question(s), scholars must consider several variables when determining the sample frame and creating control groups or quota samples. These include socio-demographic factors, such as country of origin, ethnicity (among indigenous Guatemalans in particular), age, years of formal schooling, language use and level of English proficiency, marital status, prior exposure to violence, and contextual variables (e.g. social support networks and sponsor household data) particularly in the case of multi-site research. Although the use of homogenous samples is ideal for generating statistically valid research findings, access to sufficiently large numbers of unaccompanied youth subgroups likely presents enrolment challenges, and limits the generalisability of corresponding conclusions.

Lack of culturally responsive and linguistically appropriate measures may weaken the validity and reliability of findings. Researchers report that standard psychological assessments of depression, trauma, and anxiety (e.g. the Children's Depression Inventory) result in under-reporting of symptoms when compared to qualitative data collected with the same participants, even when used with U.S. born children of undocumented immigrants (Zayas 2015). Trauma assessments (e.g. the Life Events Scale, the Harvard Trauma Questionnaire) do not assess the breath of traumatic exposures among Central American youth; fail to incorporate experiences of migration; and have not been validated in 
Spanish or other indigenous languages. Researchers must validate existing measures that are widely used with immigrant youth and develop new measures tailored to unaccompanied youth. With many schools districts eager to offer extracurricular support to newly arrived immigrant students, focus groups in schools setting could effectively accomplish these goals. Triangulation in study design also assures for interpretive validity of measures and strengthens overall rigour in data collection (Hernández, Nguyen, and Casanova, et al. 2013; Thurmond 2001).

\section{Government and community partners}

Congressional pressure on DHS and DHHS to more systematically track released youth and to expand case management services may create opportunities for collaboration and lay the groundwork for utilising large-scale quantitative methods. Scholars and practitioners (e.g. LIRS 2015) have noted, however, that immigration enforcement and the 'best interest of the child' priorities can create a conflict of interest within institutions responsible for the care of unaccompanied youth. Amidst uncertainties of immigration reform and shifts in enforcement directives, researchers are justly wary of collecting sensitive data on behalf of government entities. Absent ethically sound and transparent collaborations with these agencies, the feasibility of longitudinal research with this highlymobile, hard-to-reach population is contingent upon community networks and a wide range of service providers. The use of popular social media platforms and other free mobile phone applications to facilitate long-term follow-up could complement community-based research strategies, especially where these technologies are already in use to promote client retention.

When engaging unaccompanied youth via service provider and school networks, special precautions are critical to reduce the potential for coercion and undue influence (Hernández, Nguyen, Casanova, et al. 2013; Hopkins 2008). This is particularly true in the context of collaborations with legal service providers, First, with high rates of access to legal representation in a few metropolitan areas and multi-year backlogs in immigration proceedings, this recruitment strategy holds great promise for both accessing a representative community sample and facilitating longitudinal research. Second, legal representation remains the most decisive factor in youth's chances of remaining lawfully in the U.S. Given these high stakes, youth are more likely to perceive any communication from their attorney or legal advocate as a necessity. Service providers and researchers must use clear language in informing potential subjects that their willingness or refusal to participate would not affect services they receive or their eligibility for future services.

\section{Undocumented status}

Unaccompanied migrant youth released from detention are unique among the larger undocumented youth population in that federal authorities know their undocumented status. $^{6}$ The federal government is aware of sponsors' legal status as well; all potential sponsors are screened prior to being granted guardianship of an unaccompanied minor (GAO 2016). Since the summer of 2017, reports that federal authorities have initiated removal proceedings against sponsors of unaccompanied youth have proliferated (see, e.g. Nixon and Dickerson in The New York Times, September 24, 2017). This recent 
shift in immigration enforcement policy makes the adoption of adequate mechanisms to mitigate potential harm or breaches in anonymity or confidentiality more essential. Disclosures of any information have considerable implications and risks for both youth and members of their sponsor households. Such risks include apprehension, detention, loss of employment, stigmatisation, and deportation. For youth, subpoenaed information could potentially have an adverse effect on their eligibility for particular forms of immigration relief, thus increasing the likelihood of removal. Moreover, growing numbers of unaccompanied migrant youth remain in the U.S. following a removal order not yet carried out by DHS (Pierce 2015). In such cases, disclosure of the participant's identity and location could lead to deportation. For these reasons, all possible means of safeguarding participant anonymity, including a waiver of written consent and assent and a Certificate of Confidentiality (Hernández, Nguyen, Casanova, et al. 2013), remain critically important.

\section{Guardian consent and youth assent}

Negotiating access to unaccompanied youth requires accessing the youth's ORR-designated sponsor who can provide consent. In many cases, procedures for securing parental or guardian consent followed by youth assent pose no undue burden; however, anecdotal evidence and reports from service providers suggest that significant numbers of youth leave the care of their sponsor, complicating the process of securing such permission. In response, researchers must justify to their Institutional Review Boards (IRB) how excluding these youth introduces a sampling bias that limits the validity of collected data. In requesting a waiver of a parent/guardian permission, researchers may propose an appropriate substitute mechanism (DHHS 2009, \$46.408), such as securing the informed consent of an adult in the youth's current household, or researchers may indicate why the requirement of permission is not a reasonable requirement to protect study subjects. Another relevant argument in favour of a waiver includes an appeal to the demonstrable agency and maturity of this migrant youth population in their own cultural contexts (Heidbrink 2014). These approaches to securing informed consent are common in research with homeless and other transient youth populations (see, e.g. Ensign 2003).

In light of risks arising from participants' undocumented status, a waiver of written consent/assent can be used to eliminate any record linking subjects with the research. Acknowledging the reluctance of IRB reviewers to waive both parent/guardian consent and written consent for youth participants, some researchers have advocated for the use of witnessed consent, where another member of the research team or close acquaintance of the participant observes the oral consent process (Lahman et al. 2011). Providing participants with an information sheet that includes the researchers' contact information minimises the paper trail while ensuring participants can follow up with questions or concerns.

\section{Directions for future research with unaccompanied migrant youth}

We begin with recommendations for basic research to address the gaps in our current knowledge about unaccompanied migrant youth, including research to inform practice and services. In recognition that most teachers and service providers 'on the front lines' 
and the youth themselves cannot wait for the promises of long-term research results, we then provide suggestions for school-based services and programmes for these youth and research that evaluates their effectiveness. First, longitudinal research is critical to determine the long-term trajectories of unaccompanied youth, ranging from experiences with family reunification often after prolonged separations, finding employment, language learning, civic participation, mental health, financial responsibilities, efforts to secure legal status, and following deportation. Given that $90 \%$ of minors released to a sponsor are placed with a family member (GAO 2016, 30) and the essential role of family in determining child outcomes (Holtrop, Smith, and Scott 2015), research might explore family reunifications; shifting roles, responsibilities, and social obligations; relationships and processes; and their respective impacts on young people's health and well-being. Research might further assess the impact of placement on youths' sense of belonging; ability to remain connected to transnational familial networks; navigation of at times conflicting cultural norms; and achievement of self- and family-identified goals. This research may be particularly important among the vast majority of youth who do not receive PRS and who may pass unacknowledged by institutions and service providers. Research may further identify specific challenges experienced by youth placed in the child welfare system.

Support for young people and their families can be informed by research that identifies their internal (e.g. cultural values, psychological traits, spirituality, abilities) and ecological (e.g. family, peers, community-based organisations, churches, schools) sources of resiliency and strength. Research on the assets, capacities, and protective factors youth and their families harness can contribute to practices that build on these strengths and resist problematic positioning of youth as passive victims dependent upon adults 'to save' them (Agustín 2003).

Immigration status is perhaps the greatest immediate challenge that youth face following release. Future research can identify best practices for legal service providers and evaluate the coordination of legal services with other social service providers. Moreover, given recent troubling legal encounters (e.g. the admonition by a judge that a preschool-age child should be able to understand immigration law and hence do not need representation (see, e.g. Hennesy-Fiske (2016) in The Los Angeles Times, May 7, 2017]), research might investigate the best ways to educate legal providers about cross-cultural child development, welfare, and mental health.

One fruitful avenue for future research involves the role of schools in supporting young people following release from detention. As explained by Roth and Grace (2015), quality services for unaccompanied youth are compounding, not additive; successful experiences in school improve mental health and enhance the ability to understand and navigate legal situations. Beyond the conferral of diplomas, schools can be places where student experience belonging, become involved in nonacademic supports (e.g. extracurricular activities) and connect to community-based resources (e.g. health clinics) (Motti-Stefanidi and Masten 2013). Such experiences are protective factors against the development of mental health symptoms (Bond et al. 2007). Specific school-related questions for future research include: How do we make school relevant for unaccompanied migrant youth? How can we enhance their school readiness and engagement? What alternatives to traditional schooling exist, and do they lead to youths' academic achievement, employment, and attainment of self-identified goals? How can school-based programmes (e.g. systems of care, integrated health services) 
fill the gaps for youth who do not receive PRS? How might schools be places of belonging that offset potential risks (e.g. gang involvement)?

While the aforementioned research may inform future practice, the reality is that schools, clinics, families, and youth need answers today. One potential strategy to expand mental health services for unaccompanied youth involves school-based health centres (SBHCs), a model of service delivery that co-locates health and social services within schools, to implement innovative, multidisciplinary, and cross-sector solutions to improve the delivery of services for unaccompanied youth (Schapiro et al. 2016). Unfortunately, the limited number of SBHCs nationwide (approximately 2300) and their reliance on payment structures that exclude participation of undocumented people, may constrain their benefit for these youth (Acosta Price 2016). Cultural adaptations to empirically supported school mental health interventions informed by community leaders, cultural brokers, and families have demonstrated local success and offer promising future directions for educators and health providers working together to create nurturing school environments to foster positive school experiences for their most vulnerable students (Acosta Price et al. 2012). Developing and then evaluating school-based health and social services relevant and available to unaccompanied youth is a fruitful direction for future scholarship.

Finally, in basic research and programme development and evaluation, two additional considerations are important to bear in mind: First, methodologically and ethically sound research is often context dependent (e.g. is the youth placed with family; does he/she have access to social services; has her/his immigration case been adjudicated?). Second, this paper has focused on the unique needs of unaccompanied children and youth. While it can be argued that this subset of young people has unique needs, it is also critical to understand the shared experiences of migration across juridical categories. In some ways, the needs of youth identified as 'unaccompanied' may not be so different from the needs of undocumented youth who cross as accompanied or those who evade apprehension. These juridical, and in many ways arbitrary, distinctions may marginalise some groups of youth (e.g. undocumented youth) and reinforce problematic narratives about 'deserving' versus 'un-deserving' groups of migrant children (Heidbrink 2014). Given that many unaccompanied youth will remain in the U.S. and contribute to our communities, crafting empirically informed policies and practices is essential from humanitarian, civic, and economic perspectives.

\section{Notes}

1. This statutory definition of an unaccompanied minor is a child, under the age of 18 , without lawful immigration status who is apprehended in the U.S. and is without a legal guardian in the U.S. or within geographic proximity at the time of the child's apprehension (Manuel and Garcia 2016, 2). Until recently, the juridical term has been 'unaccompanied alien children'. In contrast, we utilise the term unaccompanied migrant youth because it more accurately reflects the demographics of young people we reference (majority of youth are 15-17 years old) (ORR 2016) and, importantly, avoids the stigmatization of terms such as 'alien'. For further discussion of the definitional challenges related to scholarship on unaccompanied children, see Menjívar and Perreira's introduction to this special issue.

2. Absent protection under TVPRA, the majority of Mexican youth elect to voluntarily return to Mexico or face expedited removal.

3. Distinguishing what is known about unaccompanied youth from what is known about undocumented children generally is challenging. Though unaccompanied child migration is not a 
new phenomenon, TVPRA-mandated changes in how these youth are processed through the U.S. immigration system have drawn attention to the unique integration experiences of this subset of immigrant children. These procedural changes have given rise to a nascent scholarship in the U.S. focused specifically on unaccompanied youth released into sponsor care. Prior research among immigrant children in the U.S. infrequently distinguished between accompanied and unaccompanied youth, making it difficult to determine in retrospect how many youth in a given sample were unaccompanied. Throughout the article, we have attempted to signal those studies involving unaccompanied youth, while recognizing that ambiguity around their representation in the broader literature on undocumented children is largely the result of the evolving nomenclature of immigration.

4. For information about unaccompanied migrant youth in Europe, see Kanics, Senovilla Hernández, and Touzenis (2010) and Menjívar and Perrerira's introduction to this special issue.

5. For more detail on immigration benefits available to unaccompanied youth, see ILRC (2014).

6. Here we are referring to the juridical category of 'unaccompanied children', encompassing only those children apprehended and detained by federal authorities. A considerable number of young people, accompanied and unaccompanied, arrive to the U.S. and evade apprehension.

\section{Acknowledgements}

This manuscript is a product of inter-disciplinary collaborations originating from the 'Undocumented, Unaccompanied, and Citizen: Charting Research Directions for Children of Immigration' Conference held at the University of Texas, Austin, February 25-26, 2016.

\section{Disclosure statement}

No potential conflict of interest was reported by the authors.

\section{Funding}

This work was supported by the National Institute on Minority Health and Health Disparities under Grant [R13 MD010415-01].

\section{References}

Abrego, L. J., and R. G. Gonzales. 2013. "Blocked Paths, Uncertain Futures: The Postsecondary Education and Labor Market Prospects of Undocumented Latino Youth." Journal of Education for Students Placed at Risk. 15: 144-157. doi:10.1080/10824661003635168.

Acosta Price, O. 2016. School-centered Approaches to Improve Community Health: Lessons from School-Based Health Centers. Washington, DC: Brookings Institution. Accessed July 31, 2016. https://www.brookings.edu/wp-content/uploads/2016/07/Price-Layout2-1.pdf.

Acosta Price, O., B. H. Ellis, P. V. Escudero, K. Huffman-Gottschling, M. A. Sander, and D. Birman. 2012. "Implementing Trauma Interventions in Schools: Addressing the Immigrant and Refugee Experience." In Health Disparities Among Under-Served Populations: Implications for Research, Policy, and Praxis (Advances in Education in Diverse Communities: Research, Policy and Praxis, Volume 9), edited by S. R. Notaro, 95-119. Bingley: Emerald Group. doi:10.1108/S1479-358X (2012)0000009008.

Agustín, L. 2003. “Forget Victimization: Granting Agency to Migrants." Development 46 (3): 30-36. doi:10.1177/10116370030463005.

AI (Amnesty International). 2010. Invisible Victims: Migrants on the Move in Mexico. London. http://www.amnestyusa.org/sites/default/files/amr410142010eng.pdf.

AIC (American Immigration Council). 2012. Public Education for Immigrant Students: States Challenge the Supreme Court's Decision in Plyler v. Doe. Washington, DC. Accessed July 31, 
2016. https://www.americanimmigrationcouncil.org/sites/default/files/research/public_educati on_for_immigrant_students.pdf.

Aldarondo, E., and R. Becker. 2011. "Promoting the Well-Being of Unaccompanied Immigrant Minors." In Creating Infrastructure for Latino Mental Health, edited by L. P. Buki and L. M. Piedra, 195-214. New York: Springer.

Alvarez, K., and M. Alegria. 2016. "Understanding and Addressing the Needs of Unaccompanied Immigrant Minors.” American Psychological Association, June. Accessed July 31, 2016. http:// www.apa.org/pi/families/resources/newsletter/2016/06/immigrant-minors.aspx.

Artico, C. I. 2003. Latino Families Broken by Immigration: The Adolescent's Perceptions. New York: LFB Scholarly.

Bean, F. D., M. A. Leach, S. K. Brown, J. D. Bachmeier, and J. R. Hipp. 2011. "The Educational Legacy of Unauthorized Migration: Comparisons across US-immigrant Groups in How Parents' Status Affects Their Offspring." International Migration Review 45 (2): 348-385. doi:10.1111/j.1747-7379.2011.00851.x.

Berger Cardoso, J. 2017. Trauma and Substance Use in Unaccompanied Migrant Youth in Texas. Houston, TX: National Hispanic and Latino Addiction Technology Center Network.

Birman, Dina. 2005. "Ethical Issues in Research with Immigrants and Refugees." In Handbook of Ethical Research with Ethnocultural Populations and Communities, edited by J. E. Trimble and C. B. Fisher, 155-177. London: SAGE.

Bond, L., H. Butler, L. Thomas, T. Carlin, S. Glover, G. Bowes, and B. Patton. 2007. "Social and School Connectedness in Early Secondary School as Predictors of Late Teenage Substance Use, Mental Health, and Academic Outcomes." Journal of Adolescent Health 40 (4): 357.e9357e18. doi:10.1016/j.jadohealth.2006.10.013.

Booi, Z., C. Callahan, G. Fugere, M. Harris, A. Hughes, A. Kramarczuk, C. Kurtz, R. Reyes, and S. Swaminathan. 2016. Ensuring Every Undocumented Student Succeeds: A Report on Access to Public Education for Undocumented Children. Washington, DC: Georgetown Law Human Rights Institute. Accessed December 28, 2016. https://www.law.georgetown.edu/academics/ centers-institutes/human-rights-institute/events/upload/2015-16-HRI-Fact-Finding-Report.PDF.

Carlson, B. E., J. Cacciatore, and B. Klimek. 2012. "A Risk and Resilience Perspective on Unaccompanied Refugee Minors." Social Work: A Journal of the National Association of Social Workers 57 (3): 259-269.

CBP (United States Customs and Border Protection). 2015. "Southwest Border Unaccompanied Alien Children FY 2014.” Accessed July 31, 2016. https://www.cbp.gov/newsroom/stats/ southwest-border-unaccompanied-children/fy-2014.

CBP (United States Customs and Border Protection). 2016. "United States Border Patrol Southwest Family Unit Subject and Unaccompanied Alien Children Apprehensions Fiscal Year 2016." Accessed September 15, 2016. https://www.cbp.gov/newsroom/stats/southwest-border-unacco mpanied-children/fy-2016.

Chavez, L., and C. Menjívar. 2010. "Children Without Borders: A Mapping of the Literature on Unaccompanied Migrant Children to the United States." International Migration 5 (3): $72-111$.

Ciacca, K. A., and R. M. John. 2016. “Unaccompanied Immigrant Minors: Where to Begin.” Journal of Pediatric Health Care 30 (3): 231-240. doi:10.1016/j.pedhc.2015.12.009.

Council of the City of New York Office of Communications. 2015. "Speaker Mark-Viverito and New York City Council: Unaccompanied Minors Representation Crisis Ended in NYC. Press Release, July 20. Accessed May 7, 2017. http://council.nyc.gov/press/2015/07/20/195/.

Crea, T., A. Lopez, T. Taylor, and D. Underwood. 2017. "Unaccompanied Migrant Children in the United States: Predictors of Placement Stability in Long Term Foster Care." Children and Youth Services Review 73: 93-99. doi:10.1016/j.childyouth.2016.12.009.

Dabach, D. B. 2011. "Teachers as Agents of Reception: An Analysis of Teacher Preference for Immigrant-Origin Second Language Learners.” The New Educator 7 (1): 66-86. doi:10.1080/ 1547688X.2011.551736.

De Genova, N., and N. Peutz, eds. 2010. The Deportation Regime: Sovereignty, Space, and the Freedom of Movement. Durham: Duke University Press. 
DOE (United States Department of Education). 2014. Fact Sheet: Educational Services for Immigrant Children and Those Recently Arrived to the United States. Washington, DC. Accessed May 7, 2017. http://www2.ed.gov/policy/rights/guid/unaccompanied-children.pdf.

Donato, K. M., and B. Sisk. 2015. "Children's Migration to the United States from Mexico and Central America: Evidence from Mexican and Latino American Migration Projects.” Journal of Migration and Human Security 3 (1): 58-79. doi:10.14240/jmhs.v3i1.43.

Ensign, J. 2003. "Ethical Issues in Qualitative Health Research with Homeless Youths." Journal of Advanced Nursing, 43: 43-50. doi:10.1046/j.1365-2648.2003.02671.x.

Falicov, C. J. 2014. Latino Families in Therapy. New York: Guilford Press.

GAO (United States General Accountability Office). 2016. Unaccompanied Children: HHS Can Take Further Actions to Monitor Their Care. GAO-16-180, February 5. Accessed July 31, 2016. http://www.gao.gov/assets/680/675001.pdf.

German, M. 2004. "Enabling Reconnection: Educational Psychologist Supporting Unaccompanied, Separated, Asylum-Seeker/Refugee Children.” Educational \& Child Psychology 21 (3): 6-29.

Gindling, T. H., and S. Poggio. 2012. "Family Separation and Reunification as a Factor in the Educational Success of Immigrant Children." Journal of Ethnic and Migration Studies 38 (7): 1155-1173. doi:10.1080/1369183X.2012.681458.

Gonzales, R. G. 2015. Lives in Limbo: Undocumented and Coming of Age in America. Oakland: University of California Press.

Goździak, E. M. 2015. What Kind of Welcome? Integration of Central American Unaccompanied Children into Local Communities. Washington, DC: Georgetown University Institute for the Study of International Migration. Accessed July 31, 2016. https://isim.georgetown.edu/sites/ isim/files/files/upload/Kaplan\%20UAC\%20Report.compressed\%20(2).pdf.

Heckathorn, D. 2002. "Respondent Driven Sampling II: Deriving Statistically Valid Population Estimates from Chain-Referral Samples of Hidden Populations." Social Problems 39: 11-34.

Heidbrink, L. 2014. Migrant Youth, Transnational Families and the State: Care and Contested Interests. Philadelphia: University of Pennsylvania Press.

Hennesy-Fiske, M. 2016. "This Judge Says Toddlers Can Defend Themselves in Immigration Court." The Los Angeles Times, March 6. Accessed May 7, 2017. http://www.latimes.com/ nation/immigration/la-na-immigration-judge-20160306-story.html.

Hernández, M. G., J. Nguyen, S. Casanova, C. Suárez-Orozco, and C. L. Saetermoe. 2013. “Doing No Harm and Getting It Right: Guidelines for Ethical Research with Immigrant Communities." In Frameworks and Ethics for Research with Immigrants: New Directions for Child and Adolescent Development, Number 141w, edited by M. G. Hernández, J. Nguyen, S. Casanova, C. Suárez-Orozco, and C. L. Saetermoe, 43-60. San Francisco, CA: Jossey-Bass.

Hernández, M. G., J. Nguyen, C. L. Saetermoe, and C. Suárez-Orozco. 2013. Frameworks and Ethics for Research with Immigrants: New Directions for Child and Adolescent Development, Number 141. San Francisco, CA: Jossey-Bass.

Holtrop, K., S. M. Smith, and J. C. Scott. 2015. “Associations Between Positive Parenting Practices and Child Externalizing Behavior in Underserved Latino Immigrant Families." Family Process 54 (2): 359-375. doi:10.1111/famp.12105.

Hopkins, P. 2008. "Ethical Issues in Research with Unaccompanied Asylum-Seeking Children." Children's Geographies 6 (1): 37-48. doi:10.1080/14733280701791884.

Huemer, J., N. S. Karnik, S. Voelkl-Kernstock, E. Granditsch, K. Dervic, M. H. Friedrich, and H. Steiner. 2009. "Mental Health Issues in Unaccompanied Refugee Minors." Child and Adolescent Psychiatry and Mental Health 3 (13), doi:10.1186/1753-2000-3-13.

ILRC (Immigrant Legal Resource Center). 2014. Unaccompanied Immigrant Children Resources. San Francisco. Accessed May 7, 2017. https://www.ilrc.org/sites/default/files/resources/ilrc_ uac_best_resources_final_9_10_14.pdf.

Infante, C., A. J. Idrovo, M. S. Sánchez-Domínguez, S. Vinhas, and T. Gonzalez-Vasquez. 2011. "Violence Committed Against Migrants in Transit: Experiences on the Northern Mexican Border." Journal of Immigrant and Minority Health 14 (3): 449-459. doi:10.1007/s10903-0119489-y. 
Irizarry, J. G., and T. Kleyn. 2011. "Immigration and Education in the "Supposed Land of Opportunity": Youth Perspectives on Living and Learning in the United States." The New Educator 7 (1): 5-26. doi:10.1080/1547688X.2011.551731.

Jani, J., D. Underwood, and J. Ranweiler. 2016. "Hope as a Crucial Factor in Integration among Unaccompanied Immigrant Youth in the USA: A Pilot Project." Journal of International Migration and Integration 17 (4): 1195-1209. doi:10.1007/s12134-015-0457-6.

Kandel, W. A. 2016. Unaccompanied Alien Children: An Overview. CRS Report No. R43599. Washington, DC: Congressional Research Service. Accessed December 28, 2016. https://fas. org/sgp/crs/homesec/R43599.pdf.

Kanics, J., D. Senovilla Hernández, and K. Touzenis, eds. 2010. Migrating Alone: Unaccompanied and Separated Children's Migration to Europe. United Nations Educational, Scientific and Cultural Organization. Accessed 28 December 2016. http://unesdoc.unesco.org/images/0019/ 001907/190796e.pdf.

Kennedy, E. G. 2013. "Unnecessary Suffering: Potential Unmet Mental Health Needs of Unaccompanied Alien Children.” JAMA Pediatrics 167 (4): 319-320. doi:10.1001/ jamapediatrics.2013.1382.

Kessler, R. C., S. Avenevoli, K. A. McLaughlin, K. Greif Green, M. D. Lakoma, M. Petukhova, D. S. Pine, N. A. Sampson, A. M. Zaslavsky, and K. R. Merikangas. 2012. "Lifetime Comorbidity of DSM-IV Disorders in the NCS-R Adolescent Supplement (NCA-A)." Psychological Medicine 43 (2): 1997-2010.

Lahman, M. K. E., B. M. Mendoza, K. L. Rodriguez, and J. L. Schwartz. 2011. "Undocumented Research Participants: Ethics and Protection in a Time of Fear." Hispanic Journal of Behavioral Sciences 33 (3): 304-322. doi:10.1177/0739986311414162.

LIRS (Lutheran Immigration and Refugee Service). 2015. At the Crossroads for Unaccompanied Migrant Children: Policy, Practice, and Protection. Baltimore. Accessed July 31, 2016. http:// lirs.org/wp-content/uploads/2015/07/LIRS_RoundtableReport_WEB.pdf.

Manuel, K. M., and M. J. Garcia. 2016. Unaccompanied Alien Children - Legal Issues: Answers to Frequently Asked Questions. CRS Report No. R43623. Washington, DC: Congressional Research Service. Accessed December 28, 2016. https://www.fas.org/sgp/crs/homesec/R43623. pdf.

Martinez, I. 2009. "What's Age Gotta Do With It?: Understanding the Age-Identities and SchoolGoing Practices of Mexican Immigrant Youth in New York City.” The High School Journal 92 (4): 34-48.

Martinez, I. 2016. "Supporting Two Households: Unaccompanied Mexican Minors and Their Absence from U.S. Schools." Journal of Latinos and Education 15 (3): 229-243. doi:10.1080/ 15348431.2015.1131690.

Menjívar, C., and K. M. Perreira. 2017. "Undocumented and Unaccompanied: Children of Migration in the European Union and the United States." Journal of Ethnic and Migration Studies. doi:10.1080/1369183X.2017.1404255.

Mitchell, C. 2015. "In US Schools, Undocumented Youths Strive to Adjust." Education Digest 81 (1): 9-13.

Motti-Stefanidi, F., and A. Masten. 2013. "School Success and School Engagement of Immigrant Children and Adolescents: A Risk and Resilience Developmental Perspective." European Psychologist 18 (2): 126-135. 10.1027/1016-9040/a000139.

Nixon, R., and C. Dickerson. 2017. "Immigration Officials Taking New Steps to Discourage Smuggling of Children.” The New York Times, September 24. Accessed October 12, 2017. https://www.nytimes.com/2017/09/24/us/politics/parents-illegal-immigrants-human-smuggling. html.

Olwig, K. F., and E. Gullov, eds. 2013. Children's Places: Cross-Cultural Perspectives. New York: Routledge.

Orellana, X. 2013. "Sitiados centros educativos por las maras en Honduras" La Prensa, September 3. Accessed May 7, 2017. http://www.laprensa.hn/especiales/381915-273/sitiadoscentros-educativos-por-las-maras-en-honduras. 
ORR (Office of Refugee Resettlement). 2016. "Facts and Data.” Accessed September 15, 2016. http:// www.acf.hhs.gov/orr/about/ucs/facts-and-data.

Perez, W., R. Espinoza, K. Ramos, H. M. Coronado, and R. Cortes. 2009. “Academic Resilience among Undocumented Latino Students.” Hispanic Journal of Behavioral Sciences 31 (2): 149181. doi:10.1177/0739986309333020.

Perreira, K., and I. Ornelas. 2013. "Painful Passages: Traumatic Experiences and Post-Traumatic Stress among Immigrant Latino Adolescents and Their Primary Caregivers." International Migration Review 47 (4): 976-1005. doi:10.1111/imre.12050.

Pierce, S. 2015. Unaccompanied Child Migrants in U.S. Communities, Immigration Courts, and Schools. Washington, DC: Migration Policy Institute. Accessed July 31, 2016. http://www. migrationpolicy.org/research/unaccompanied-child-migrants-us-communities-immigration-co urt-and-schools.

Pumariega, A. J., and E. Rothe. 2010. "Leaving No Child or Families Outside: The Challenge of Immigration." The American Journal of Orthopsychiatry 80 (4): 505-515. doi:10.1111/j.19390025.2010.01053.x.

Rae-Espinoza, H. 2016. “Transnational Ties: Children's Reactions to Parental Emigration in Guayaquil, Ecuador.” Ethos (berkeley, Calif ) 44 (1): 32-49. doi:10.1111/etho.12111.

Roth, B. J., and B. L. Grace. 2015. "Falling Through the Cracks: The Paradox of Post-Release Services for Unaccompanied Child Migrants.” Children \& Youth Services Review 58: 244-252. doi:10.1016/j.childyouth.2015.10.007.

Schapiro, N. A., J. R. Gutierrez, J. L. Gonzalez, J. S. Dai, and I. Gutierrez. 2016. "Unaccompanied Minors: Breaking Down Barriers to Health.” Journal of Adolescent Health 58 (2): S21. doi:10. 1016/j.jadohealth.2015.10.056.

Shonkoff, J. P., A. S. Garner, The Committee on Psychosocial Aspects of Child and Family Health, Committee on Early Childhood, Adoption, Dependent Care, and Section on Developmental and Behavioral Pediatrics, B. S. Siegel, M. I. Dobbins, M. F. Earls, A. S. Garner, L. McGuinn, J. Pascoe, and D. L. Wood. 2012. "The Lifelong Effects of Childhood Adversity and Toxic Stress." Pediatrics 129: e232-e246. doi:10.1542/peds.2011-2663.

Smid, G. E., G. J. Lensvelt-Mulders, J. W. Knipscheer, B. P. Gersons, and R. J. Kleber. 2011. "LateOnset PTSD in Unaccompanied Refugee Minors: Exploring the Predictive Utility of Depression and Anxiety Symptoms." Journal of Clinical Child \& Adolescent Psychology 40 (5): 742-755. doi:10.1080/15374416.2011.597083.

Smith, A., R. N. Lalonde, and S. Johnson. 2004. "Serial Migration and Its Implications for the Parent-Child Relationship: A Retrospective Analysis of the Experiences of the Children of Caribbean Immigrants." Cultural Diversity and Ethnic Minority Psychology 10 (2): 107-122. doi:10.1037/1099-9809.10.2.107.

Stinchcomb, D., and E. Hershberg. 2014. Unaccompanied Migrant Children from Central America: Context, Causes, and Responses. Washington, DC: American University Center for Latin American \& Latino Studies. Accessed July 31, 2016. http://ssrn.com/abstract=2524001.

Suárez-Orozco, C., H. J. Bang, and H. Y. Kim. 2010. "I Felt Like My Heart Was Staying Behind: Psychological Implications of Family Separations and Reunifications for Immigrant Youth.” Journal of Adolescent Research 26 (2): 222-257. doi:10.1177/0743558410376830.

Suárez-Orozco, C., and A. Carhill. 2008. "Afterword: New Directions in Research with Immigrant Youth and Their Families." In New Directions for Youth Development: Theory, Practice, and Research, Volume 121, edited by H. Yoshikawa and N. Way, 87-104. San Francisco, CA: Jossey-Bass.

Suárez-Orozco, C., I. L. G. Todorova, and J. Louie. 2002. "Making Up for Lost Time: The Experience of Separation and Reunification among Immigrant Families." Family Process 41: 625-643. doi:10.1111/j.1545-5300.2002.00625.x.

Taxin, Amy. 2016. “AP Exclusive: Children's Asylum Approvals Vary by US Region.” Associated Press, June 1. Accessed July 31, 2016. http://bigstory.ap.org/article/b140ad95d4a646e9aff67b8c 80708e57/ap-exclusive-childrens-asylum-approvals-vary-us-region.

Thurmond, V. A. 2001. “The Point of Triangulation.” Journal of Nursing Scholarship 33 (3): 253258. doi:10.1111/j.1547-5069.2001.00253.x. 
TRAC (Transactional Records Access Clearinghouse). 2014. "Representation for Unaccompanied Children in Immigration Court.” Accessed July 31, 2016. http://trac.syr.edu/immigration/ reports/371/.

UNHCR (United Nations High Commissioner for Refugees). 2014. Children on the Run: Unaccompanied Children Leaving Central America and Mexico and the Need for International Protection. Washington, DC. http://www.unhcr.org/56fc266f4.html.

UNODC (United Nations Office on Drugs and Crime). 2014. Global Study on Homicide 2013. Vienna. Accessed July 31, 2016. https://www.unodc.org/documents/gsh/pdfs/2014_GLOBAL_ HOMICIDE_BOOK_web.pdf.

USCCB (United States Catholic Conference of Bishops). 2012. The Changing Face of the Unaccompanied Alien Child: A Portrait of Foreign-Born Children in Federal Foster Care and How to Best Meet Their Needs. Washington, DC. Accessed May 7, 2017. http://www.usccb. org/about/children-and-migration/unaccompanied-refugee-minor-program/upload/A-Portraitof-Foreign-Born-Children-in-Federal-Foster-Care-and-How-to-Best-Meet-Their-Needs_USCC B-December-2012.pdf.

U.S. Senate. 2016. Protecting Unaccompanied Alien Children from Trafficking and Other Abuses: The Role of the Office of Refugee Resettlement. Washington, DC: Permanent Subcommittee on Investigations. Accessed September 15, 2016. http://www.hsgac.senate.gov/subcommittees/ investigations/hearings/adequacy-of-the-department-of-health-and-human-services-efforts-toprotect-unaccompanied-alien-children-from-human-trafficking.

Vervliet, M., J. Lammertyn, E. Broekaert, and I. Derluyn. 2014. "Longitudinal Follow-up of the Mental Health of Unaccompanied Refugee Minors." European Child \& Adolescent Psychiatry 23 (5): 337-346. doi:10.1007/s00787-013-0463-1.

Wang, P. S., M. Lane, M. Olfson, H. A. Pincus, K. B. Wells, and R. C. Kessler. 2005. “Twelve-Month Use of Mental Health Services in the United States: Results from the National Comorbidity Survey Replication." Archives of General Psychiatry 62 (6): 629-640. doi:10.1001/archpsyc.62. 6.629.

Waters, M. C., and M. G. Pineau, eds. 2015. "Legal Status and Immigrant Integration." Chap. 3 in The Integration of Immigrants into American Society, 93-158. Washington, DC: National Academies Press. Accessed July 31, 2016. https://www.nap.edu/read/21746/chapter/5.

White House Office of the Press Secretary. 2014. "Fact Sheet: Expanding Access to Legal Representation.” Press Release, October 22. Accessed July 31, 2016. https://www.whitehouse. gov/the-press-office/2014/09/30/fact-sheet-expanding-access-legal-representation.

Zayas, L. H. 2015. Forgotten Citizens: Deportation, Children, and the Making of American Exiles and Orphans. New York: Oxford.

Zinth, J. D. 2013. English Language Learners: A Growing - Yet Underserved - Student Population. Education Commission of the States. Accessed May 7, 2017. http://www.schoolturnaroundsupp ort.org/sites/default/files/resources/http cl.exct_.pdf.

Zychinski, K. E., and A. J. Polo. 2012. "Academic Achievement and Depressive Symptoms in Lowincome Latino Youth.” Journal of Child and Family Studies 21 (4): 565-577. 